\title{
Art in the inclusion of children with special needs in dentistry
}

\section{A arte na inclusão da criança especial na odontologia}

M arcio J osé Possari dos Santos ${ }^{1}$

Sandra M aria H erondina Coelho Ávila de Aguiar ${ }^{1}$

${ }^{1}$ Faculdade de O dontologia

deAraçatuba, Unesp. Rua

José Bonifácio 1193, Vila

M endonça. 16015-110

Araçatuba SP.

mpossari@foa.unesp.br

\begin{abstract}
The purpose of this study was to report the use of art and its segments as a source for inclusion of the children with special needs in dentistry. The application of the Art in social therapy activities and workshops was divided in modules: Session of Socialization, Complementary Workshops of Art and Activities, aiming at the cultural anamnesis and artistic preferences of the 313 participants, prior to their dental care treatment at CAOE (Center of Odontological Assistance to patients with special needs) - FOA U nesp. According to preference of the participants that answered the questionnaires, the music and the painting are the artistic segments that proved to be most helpful in the activities of inclusion and adaptation. The authors concluded that the use of art in the adaptation and environmental inclusion of the patient, prior to dental procedures is favorable and efficient.

Key words Art, Adaptation, Behavioral sciences, Dentistry
\end{abstract}

Resumo A proposta desteestudo érelatar a utilização da artee seus segmentos, como recurso para inclusão da criança portadora de necessidades especiais ao ambiente odontológico. Foi utilizado como método a aplicação da arteem atividades de socioterapia eoficinas, divididas em módulos: sessão de socialização, oficinas de arte e atividades complementares, visando à elaboração de uma anamnese cultural por meio de questionários ea obtenção das preferências artísticas dos 313 participantes, previamente às suas assistências odontológicas no CAOE (Centro de Assistência O dontológica a Portadores de N ecessi dades Especiais) FOA/U nesp. De acordo com os questionários respondidos, a música ea pintura, segundo a preferência dos participantes, são os segmentos artísticos que mais auxiliam nas atividades de inclusão e adaptação. Concluímos quea utilização da arte na adaptação e inclusão ambiental do paciente, previamente à assistência odontológica, é favorável e eficaz.

Palavras-chave Arte, Adaptação, Ciências do comportamento, O dontologia 


\section{Introduction}

Studies on art as applied in physical surroundings in the health care area and its relation to human behavior have been increasingly investigated, and the favorable results thereof suggest the use of artistic segments as a positive auxiliary approach in thetherapeutic treatment and in the patient's inclusion at the dental care practice ${ }^{1}$.

Based on the work carried out by the group of performers "Doctors of Joy", experienced in clown theatricals and circustechniques developed in hospitals, the character and performance of theclown were inserted in the children's stimulation and recovery process; in theparticipation of parents and to minimize stress on the part of the health care team ${ }^{2,3}$.

Ludic activity during childhood promotes expression, communication and integration of the individual in social groups, and may be another approach for the orientation and identification of knowledge on health education habits; but as regards disabled children it is little used ${ }^{4,5}$.

M otivation is a psychological factor related to physical activity, whether under the aspect of learning or performance ${ }^{6}$. Some studies have postulates in common, promoting dentistry motivation and guidance, making use of artistic means such as music, theatricals, puppetry and videos, among others ${ }^{7-10}$.

Regardless of their specific aims (learning, personal development, team management, work meetings, etc), group dynamics definitely contributetowards facilitating and improving group action, thus enhancing integration and better direction for the goals established ${ }^{11,12}$.

The use of music and dance as ancillary resourcefor stimulating sensorial experimentation (rhythm, motor development and socialization) ${ }^{6}$ represents a possibility of treatment for children with cerebral palsy ${ }^{13}$, and for people who seek psychiatric hel $p^{14}$.

Music therapy is used for people with some kind of disability, psychical disturbances (depression, autism, schizophrenia) ${ }^{15-17}$, and in geriatric care or for those seeking self development, according to the definition given by music therapist Renato Tocantins Sampaio ${ }^{18}$.

According to psychologist Elidihara Trigueiro ${ }^{18}$, music may not be the main focus of a treatment as in music therapy but, as in the case of psychic music, it can be one of the valuable means of dealing with psychical matters.

M usical art, used in favor of health care, opens new possibilities of communication, starting with an expression at a concrete level (musical instruments and/or musical stimuli), with theobject of attaining the symbolic level. The modality may beused individually, or in a family group, in community works or groups ${ }^{16,18}$, contributing to the development of the intelligence quotient of individuals ${ }^{19}$.

Results obtained by Bustillo et al. ${ }^{20}$ indicated the inclusion of Music therapy and/or children stories as two major aids for pediatric dentistry treatment by helping children to relax.

Painting is another form of expression that enables the understanding of the human being in its bio-psychosocial development and in the contextualization of data, the history of psychological aspects ${ }^{21}$. In the treatment of psychoses, expressive, non-verbal techniques of therapeutic nature have been used, the main object of which is to enable patients to build their own process, in which they can recognize themselves ${ }^{22}$.

Cinema renders the spectator in a special psycho-physiological state (physical state of sensorial fascination), to introduce its messages by means of images, words, music and silence; and is considered, among all others, the most complete means of artistic communication ${ }^{23}$.

Fairy taleshavethe capacity to interlink theconsciousand unconsciousmind. In ancient times, they were part of one'supbringing, crammed with mystery and affections in the quest for psychic totality ${ }^{24}$. Traditional children's games led to the discovery of a"spontaneous" phenomenon, with no adult planning or written approach ${ }^{25}$.

Figueira ${ }^{26}$ dealt with disabled patients' relationships with many forms of art: dance, plastic arts, music, Brazilian Baroque and movies, even revealing some names of well known personalities who had been involved with some type of disability.

Thus, it is believed that the investigation of such factors is important, not only for a better description of the benefits brought about by art and its artistic segments, but also for the understanding of the relationships among members of the group and as the transmission of culture by way of play.

The purpose of this study was to report on the use of art and its artistic segments, as a resource for inclusion of special needs children in dentistry, because most of them not cooperating and does not allow the realization of their dental treatment, so the team of CAOE (Center of Dentistry Care for Special Needs Patients) - FOA/ UNESP), use techniques, resources and recreational activities to achieve their cooperation. 
Material and methods

In this project participated 92 patients with special needs, of both sexes, aged 8 to 18 years, and 221 accompanying adults, also of both sexes. It was selected patients with mental retardation from mild to moderate, so they could participate actively in the activities and who agreed to be part of the project, after receiving all information regarding the activities to be developed and their families signed the authorization to participate. All patients gave informed consent and the study was approved by the Ethics Committee.

Although not all patients who participated in this project werechildren, professionals working at CAOE usually treat them like children, because in reality they like and feel happy to betreated as such. Routinely the professionals use some re sources of entertainment, likechildren's games to attract their attention to conditioning them to achieve the desired dental procedures.

With basis on the Psycho Music philosophy, the activities of this project were organized in modules and stages, called socialization sessions, art workshops and cultural-pedagogic activities (complementary), every Tuesday morning, from 8 a.m. to 11.30 a.m.

\section{Psycho music}

Thepsychology of music deals with thenature of perceptual processes, cognitive, motor, psycho emotional and spiritual exercise of the activity involved in musical.

"The utilization of music as a resource an intervening, preventive and rehabilitating element, through relaxation sessions, will depend on the clinical case. In theinitial sessions, the person talks about his life history, his childhood, drawing up an anamnesis, including his musical identity. It is important to make it clear that the utilization of music is not bound by music therapy work, which has its own theoretical basis. There are other models that work with music and which are equally scientific, differing in techniques", according to Elidihara Trigueiro ${ }^{18}$, a psychologist from the State of Ceará, Brazil.

\section{Socialization sessions}

Group meetings, with the purpose of presenting the members' opinion and their relation with music and art in general, thus facilitating per- sonal introductions, establishing contact and the first bonds of friendship, and where each person comes to know a little more about the others. In these sessions, apart from names and places of origin, the members express their artistic tastes, making comments about the same, thus creating a closeand friendly atmosphereamong thegroup (Figure 1).

\section{Art workshops}

In these meetings, thegroup is encouraged to take interest in the musical instruments, handling them in rhythmical exercises, uttering the sound produced by elaborating musical phrases and melody lines, respecting knowledge and coordination limitations, and stimulating creative capacity (Figures 2 and 3 ).

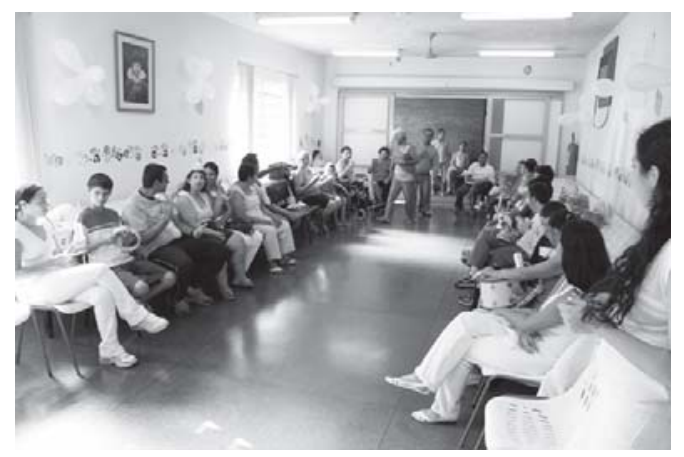

Figure 1. Socialization session.

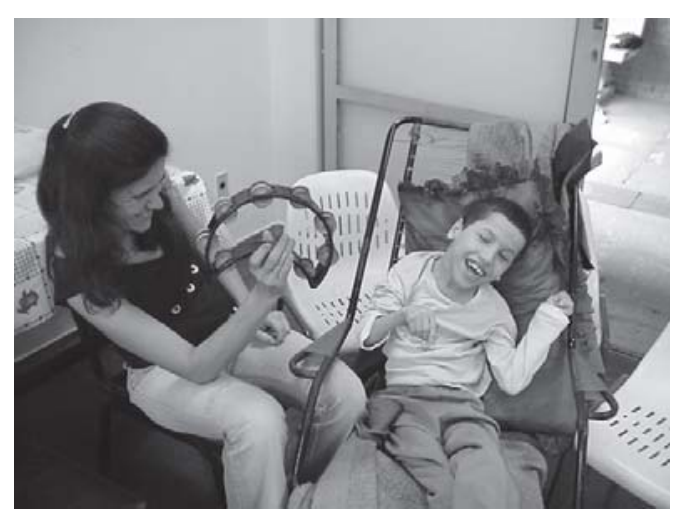

Figure 2. Stimulating the production of sounds. 


\section{Cultural pedagogical activities (complementary)}

During the period in which the patients remain at the "Centrinho", affectionate name by which the CAOE center is called, other complementary activities are given, such as: painting with dentistry teaching materials, videoke (singing in accompaniment to a video program), playing gamessimulating a situation at the dentistry clinic using a miniature consultation room, dancing, story teller, dentist of joy, magician, and other activities (Figures 4 and 5).

While this study was carried out, the sessions were coordinated by members of CAOE's multidisciplinary and interdisciplinary team, by artists, and internship graduation and post-graduation students at the Araçatuba Dentistry College - UNESP, who, by means of question forms specially designed to be answered by the participants, evaluated and registered diverse personal

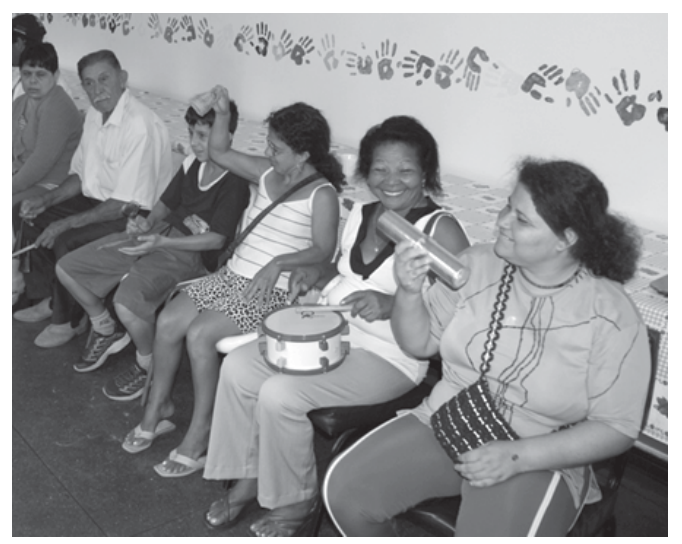

Figure 3. Working on motor coordination.

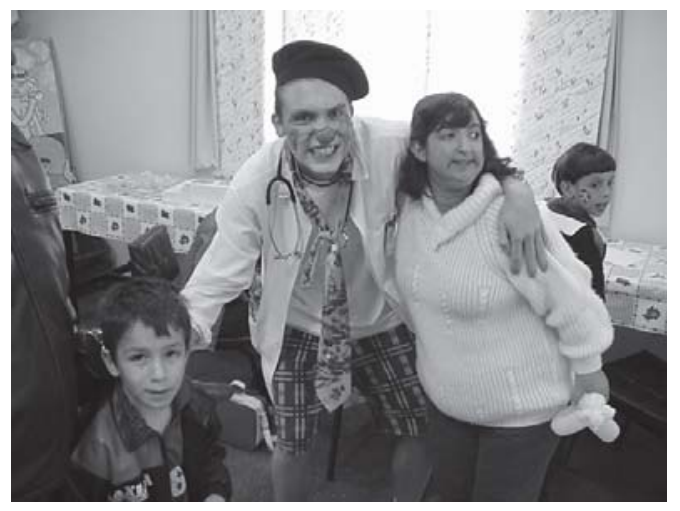

Figure 4. Doctor of Happiness. information, such as: place of origin (State), preference of musical styles, knowledge of musical instruments, artistic activities and segments, and the benefits thereof.

The data collected by the 313 question forms answered were stored in computer and later drawn up in discussion, enabling a better understanding of the results verified and how it relates with literature.

\section{Results and discussion}

Under direct influence of "Patch Adams" philosophy, that means contagious love and enthusiasm to help people, and adjusting it to our reality and culture, the physical space at the CAOE was adapted for the development of activities and dynamics covering the various artistic segments (music, painting, dance, story telling, puppetry, etc), providing our population with a special type of patient care.

Like Sager ${ }^{1}$, we noticed that children established greater associativeand parallel interactions in larger physical spaces. The results weresimilar to those of the artistic group "Doctors of Joy" ${ }^{3}$ and to the experience of the "Laughter Company"2, where some changes in the daily routine wereobserved: the "hospital" setting became more informal and easy going, the sound of laughter was frequently heard and objects, sounds, movements, colors, spaces and characters became objects of play.

The argument in favor of the healthy recovery of each child, stimulating it to "get better", is achieved with thehappy atmosphere that theartists and dynamics create in the actual setting ${ }^{3}$, enabling the patients and their chaperones to feel

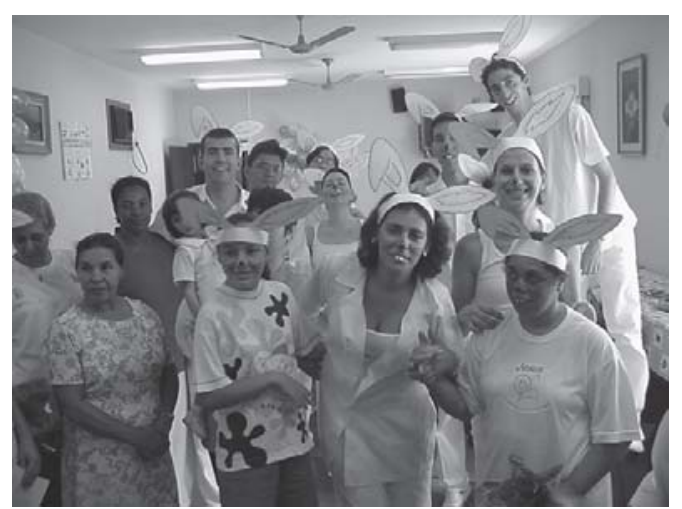

Figure 5. Use of imagination and fantasy. 
relaxed and by directing their attention to other stimuli during the waiting period, thus making the waiting room atmosphere a pleasant and welcoming one?

The confirmation that motivation, brought about by the use of artistic segments and group dynamics, is really effective and that it gives the person a more positive state of mind, coincides with the reports of several authors ${ }^{6-12}$, as the ludic component enhances sociability, facilitating and improving group action, enabling integration amongst the members and directing them to the goals established. The stimulus of sound and rhythm perceptions acts on memorization, on the display of emotions and sensibility, helping patients to become moreindependent in daily life activities, by way of exercises and play activities that promote the development of motor coordination.

By combining play and imagery to transform reality, and by developing educational health care habits with children, by means of activities such as theater plays, children stories and puppets, we are corroborating with Castro et al. ${ }^{4}$ and Jurdi ${ }^{5}$, as they have reported that in this manner it is possible to enable the special needs child, in particular, to fulfill its place in the family group, social, school and other groups.

The person's exercise of listening, of talking about a globalized idea and expressing images by way of drawings is, undoubtedly, a precious meansfor the transformation of the being into a higher emotional state, broadening its socialization ${ }^{24}$ capacity.

Having prior knowledge of the participants' preferences, according to information supplied by the artistic anamnesis, enabled us to meet their needs as observed during the dynamics. Concern for each participant's limitations and stimulation of their artistic potentials, madeleisureand recreation the facilitating links, by which the artistic segments used enabled the participants to adapt themselves to the surroundings, in an effective and affectionate manner of welcoming people to our "home" of work.

As regards the place of origin of the participants in this project, it was observed that the majority came from counties of practically every region of the State of São Paulo, probably due to easy road access and geographical localization, and the remainder came from 4 other Brazilian states (M ato Grosso do Sul, M inas Gerais, Paraná and Bahia).

However, at present the Center receives patients from 9 states and from over 380 counties, main- taining the CAOE as referencefor dentistry carefor people with special needs over the last 23 years.

Among the participants, $98.2 \%$ said they liked music, and we found $1.2 \%$ with total amusia. Regarding theartistic segments, music was found to be the preference of our population, and proved to bea valuableartistic resourcefor working with psychical problems, particularly when concerning people with some kind of disability, psychical disorders, autism, schizophrenia, syndromes ${ }^{15-17}$, similar to the results reported by the music therapist from São Paulo, Renato Tocantins Sampaio ${ }^{18}$, and by other authors ${ }^{19}$, as our population under study falls under similar neurological diagnoses.

On comparing data regarding musical preferences, a few differences were noted as, in our study, the participants gave preference to country style music, these results differ from those obtained by Bustillo et al..$^{20}$, by which the predominant choice was for eclectic music and children's music. Wemust takeinto consideration that these evaluationsweremadein different periods, which certainly justifies both results, since in any occasion there will be a predominant musical style.

In our culture, the guitar is characteristically considered a popular musical instrument, so much so that it was mentioned by most of the participants, and particularly by rousing their interest in learning to play the instrument.

In relation to preferencesfor theartistic activities (singing, painting and dancing), the patients showed greater interest in drawing (82.6\%), results similar to those reached by Pulchinelli et al. ${ }^{22}$, and Tabaquim et al. ${ }^{21}$, who reported painting as another form of expression and approach in the non-verbal techniques. However, singing was the patients' second choice option (73.9\%), but many times they were unable to do so due to difficulty of expression by means of speech, or not being able to read and also due to shyness. Dancing was the third choice option, mainly due to the religious beliefs of their chaperones and to thepatients' physical and motor impairment. This result brought forth suggestions for reevaluation regarding the utilization of dance, in order to enable new and pleasant stimulus experiences for psychomotor development, as those obtained by Braccialli $i^{13}$ and Castro ${ }^{14}$ in their studies.

And regarding cinema, we agree with Acosta Nodal ${ }^{23}$ in the sense that this is the most complete means of artistic communication but, according to our results, this option lacked interest when compared to other artistic segments, probably due to the participants' socio-economic 
circumstances and lack of opportunity or conditions to enjoy this artistic modality.

Approval of the project is justified by theparticipants' physical and emotional well-being as, after taking part in the activities, they reported feeling happy, calm and relaxed. Therefore, we believe that after participating in these activities, the patients' tend to havea better conduct during dentistry care treatment. This study is being carried out with focus on the evaluation of behavioral control, and physiological analyses of the changes that art and its segments bring about in the person's body and emotions, and on the patients' inclusion in the dentistry caresetting.

However, a small percentage of unfavorable emotional conditions and nervousness was observed, nevertheless this did not compromise the advantages of the project as these few patients habitually havethis kind of behavior, as reported by their relatives. We also observed, though in minor scale, that some patients became anxious dueto stimulus and opportunities created by the project, though this did not cause any negative changes in behavior, only acceleration of speech and the wish to repeat the activities or to stay a littlelonger doing certain exercises.

The vast experienceacquired and the changes observed, stress the need to emphasize the importance of innovating in search of resources to stimulate the process of inclusion, so that patients may feel at ease during their visits to the CAOE for dental treatment.

Figueira's ${ }^{26}$ approach on the disabled patients' relationship with the most diversearts en- abled us to observe the talent of some participants, not only in music but also in theater play and in painting.

According to Pontes and $M$ agalhães ${ }^{25}$, and results gathered in this study, we can infer that playing games and artistic manifestations represent important functions and benefits for the development of the human being.

By developing dynamics and recreational activities, and employing group techniques, methods and exercises with the participants assisted at the CAOE, we aimed at rousing interest, contact and ability with arts, with a view to stimulating, directing, giving guidance and help and, in some cases, meeting the therapeutic needs of patients, persons in charge, entities and other people concerned with care to the special needs patient; stimulating in a global manner the behavioral development of these persons, and also contributing toward the adaptation, inclusion and integration of the group analyzed in the project, and acting as another source of information for the evolution of scientific studies on the matter.

\section{Conclusion}

Face to the obtained results in thisstudy, we concluded that the use of art and its artistic segments had facilitated integration amongst the participants, promoting welfare and making them to feel happy. Thus, social inclusion facilitated the adaptation to the dentistry environment.

\section{Collaborators}

MJP Santos and SM HCÁ Aguiar participaped equaly in all the steps of the elaboration of the article. 


\section{References}

1. Sager F, Sperb TM, Roazzi A, Martins FM. Avaliação da interação de crianças em pátios de escolas infantis: uma abordagem da psicologia ambiental. Psicol Reflex Crit 2003; 16:203-215.

2. Françani GM, Zilioli D, Silva PRF, Sant'ana RPM Lima RAG. Prescrição do dia: infusão de alegria. Utilizando a arte como instrumento na assistência à criança hospitalizada. Rev. Latino-Am. Enfermagem 1998; 6:27-33.

3. Nogueira W, Masetti M. Os "doutores da alegria": um relato de experiência. M undo saúde 2000; 24:264267.

4. Castro APR, Gonçalves AF, Caetano FHP, Souza LJEX. Brincando e aprendendo saúde. Texto contexto-enferm 1998; 7:85-95.

5. Jurdi APS. Atividade lúdica: uma atividade criativa. Temas Desenvolv 2001; 10:46-50.

6. Tresca RP, De Rose Júnior D. Estudo comparativo da motivação intrínseca em escolares praticantes e não praticantes de dança. Rev Bras Ciênc M ov 2000; 8:9-13.

7. Costa EL. Como motivar adolescentes em saúde bucal: avaliação de estratégias didático-pedagógicas aplicadas em escolas públicas de São Luis-M A [dissertação]. Natal (RN): Universidade Federal do Rio Grande do Norte; 2000.

8. Santos Miele GM, Bussadori SK, Imparato JCP, Guedes-Pinto AC. Música e motivação na odontopediatria. JBP, j. bras. odontopediatr. odontol. bebê 2000; 3:414-423.

9. Zuanon ACC, Hebling J, Giro EMA. Análise do aprendizado de escolares após uma sessão de motivação. Rev O dontopediatr 1995; 4:191-198.

10. Zuanon ACC, Malagoli DM, Giro EM A. A importância do reforço constante na motivação do paciente. JBP, j. bras. odontopediatr. odontol. bebê 1999; 2:391-396.

11. Dinâmicas de Grupo. [cited 2008 Fev 25]. Available from: http://www.psicologia.com.pt/instrumentos/ dinâmicas/

12. Tavares CM . Oficina de arte: atuação terapêutica da enfermeira psiquiátrica. Rev Bras Enferm 1997; 50:569-576

13. Braccialli LMP, Ravazz RM Q. Dança: influência no desenvolvimento da criança com paralisia cerebral. Temas Desenvolv 1998; 7:22-25.

14. Castro ED. A dança, o trabalho corporal e a apropriação de si mesmo. Rev Ter Ocup 1992; 3:24-32.
15. Gold C, Wigram T, Elefant C. Musicoterapia para el transtorno de espectro autista. La Biblioteca Cochrane Plus [serial on the Internet] 2007 [cited $2008 \mathrm{Feb}$ 25]. Available from: http://cochrane.bvsalud.org/ cochrane/pdf.php?name=CD 004381-ES

16. Nick E. M usicoterapia: estudos preliminares de uma nova técnica musicoterápica para pacientes esquizofrênicos. J Bras Psiquiatr 1987; 36:185-188.

17. Ruddy $R$, Milnes D. Arteterapia para la esquizofrenia o las enfermidades similares a la esquizofrenia. La Biblioteca Cochrane Plus [serial on the Internet] 2007 [cited 2008 Feb 25]. Available from: http:// cochrane.bvsalud.org/cochrane/pdf.php?name= CD 003728-ES

18. M usicoterapia é a arte a favor da saúde. [cited 2005 Feb 12]. Available from: http://saúdeterra.com.br/ interna/0,0L193816-El1520,00.html

Greco A. Pesquisa mostra que a música aumenta

19. Q.I. J Cienc [serial on the Internet] [cited 2005 Aug 30]. Available from: http://www.jornaldaciencia. org.br/D etalhe.jps?id $=21152$

20. Bustillo GAFN, Guedes Pinto AC, Sagretti OMA. Influência da música no tratamento odontopediátrico. Rev Assoc Paul Cir Dent 1992; 46:731-734.

21. Tabaquim M LM, Moura-Ribeiro M VL, Ciasca SM Arte, desenvolvimento e excepcionalidade em obras de Diego Velázquez. Infanto Rev Neuropsiquiatr Infanc Adolesc 2001; 9:88-91.

22. Pulchinelli CC, M egale FCS, Alonso SG. Um espaço de pintura. Rev Ter Ocup 1992; 3:60-64.

23. A costa Nodal CR. Cinedebate terapéutico III. Rev Hosp Psiquiátr La Habana 1989; 30:595-610.

24. Ferreira M P. Contos de fada como atividade terapêutica. J Bras Psiquiatr 1991; 40:160-162.

25. Pontes FAR, Magalhäes CM C. A estrutura da brincadeira e a regulação das relações. Psicol Teor Pesqui 2002; 18:213-219.

26. Figueira E. A presença da pessoa com deficiência na arte: alguns apontamentos sobre artistas ou personagens. Temas Desenvolv 2002; 11:20-34.

Artigo apresentado em 10/11/2008

Aprovado em 05/06/2009

Versão final apresentada em 09/07/2008 